\title{
Postmoderne epistemologie en postkoloniale hermeneutiek ${ }^{*}$
}

\author{
Andries G van Aarde \\ Departement Nuwe-Wetenskap \\ Universiteit van Pretoria
}

\begin{abstract}
Postmodern epistemology and postcolonial hermeneutics

Postcolonial hermeneutics is concerned with linguistic, cultural and geographical transfer. Within the framework of biblical studies it explores strategies of interpreting texts from the situation of previously colonised people who are accommodated in a new liberated context, but find themselves both included and excluded. Biblical texts are historically considered to be both the products of people who were subjected to the exploitation of Middle-Eastern and Graeco-Roman super powers and interpreted today in the third world by people who also were subjects of modern colonial powers. Postcolonial studies represent a postmodern epistemology which implies a deconstructive approach to hermeneutics. The article consists of five "preludes", introducing postmodern epistemology, postcolonial hermeneutics, postcolonial biblical studies, and unlocking potential biblical research in South Africa.
\end{abstract}

\section{INLEIDING}

In die internasionale gemeenskap van Nuwe-Testamentici is Andrew $\mathrm{K} \mathrm{M}$ Adam en Stephen D Moore ${ }^{1}$ bekend vir hulle bydrae op die gebied van poststrukturele en postmoderne Bybelwetenskap. In 'n bundel wat as 'n inventaris van postmoderne begrippe, soos van toepassing op die Bybelwetenskappe, beskou kan word, naamlik die Handbook of postmodern biblical interpretation, en waarvan Adam (2000) die redakteur is, bespreek Moore (2000:182-188) "postkoloniale studies" as 'n produk van postmoderne

\footnotetext{
* Die Afrikaanse verwerking van 'n referaat wat aangebied is by die NRF-Streekkonferensie oor "Shifting boundaries of knowledge - the role of social sciences, law and humanities", 28 Mei 2004, by die Tshwane University of Technology, Pretoria. Hierdie bydrae word opgedra aan prof dr Andries Breytenbach by geleentheid van die aanvaarding van emeritaat as professor in die Ou-Testamentiese Wetenskap aan die Universiteit van Pretoria.
} 


\section{Postmoderne epistemologie en postkoloniale hermeneutiek}

kritiek. Dit geld inderdaad ook literêre studies in die algemeen. In die verband word drie publikasies wat oor "postkoloniale studies" handel, as besonder invloedryk geag, naamlik Edward Said ${ }^{2}$ (1978) se Orientalism: Western conceptions of the Orient, Gayatri Chakravorty Spivak ${ }^{3}$ (1985) se manifes "Can the subaltern speak? Speculations on widow-sacrifice" en Homi Bhabha (1994) se bundel The location of culture. Al drie hierdie kritici het voortgebou op die poststrukturele teorieë van die postmoderne Franse filosowe (Moore 2000:183), soos byvoorbeeld Foucault, Derrida en Lacan (kyk England 2004:91-96).

Die epistemologie agter postkoloniale studies kom ongetwyfeld as postmodern van aard voor. In die konteks van Suid-Afrika, as deel van Afrika, verteenwoordig dit 'n bewustheid wat as element van die hedendaagse Afrikarenaissance beskou kan word. Daar kan egter aangevoer word dat postmodernisme 'n teenstrydige benaming sou wees om die paradigma waarbinne sosiaal-wetenskaplike navorsing in Afrika bedryf behoort te word, te omskryf. Moderniteit het 'n groot deel van Afrika nog nie bereik nie en talle Afrikane is nie daarvan bewus dat hulle deel van die so genoemde "wêrelddorp" (global village) is nie. Soos ek dit sien, is dit nie die primêre bedoeling van nadenke oor paradigmas en paradigmaveranderings om mense se grense te verskuif sodat "pre-moderne mense" "moderne mense" of "moderne mense" "postmoderne mense" word nie. Om "grense van kennis te verskuif" ${ }^{4}$ ten einde te bepaal wat plaaslik relevante en internasionaal mededingende navorsing binne die Afrika-konteks sou wees, vereis 'n besinning oor geskikte epistemologieë op teoretiese vlak. Dit is teen hierdie agtergrond dat ek geïnteresseerd is om te weet watter "ken-wyses" toepaslik sou kon wees vir sosiale wetenskaplikes om modelle en metodes te ontwerp wat die diverse realiteite van die Afrika-konteks kan ontleed en verklaar, ten einde 'n outentieke bestaan te bevorder en om menslike hulpbronne te bemagtig. Afgesien van die tegnologiese bydrae van die sogenaamde "harde wetenskappe" het ons wêreld ook 'n behoefte aan die bydrae van die sosiale wetenskappe, insluitend teologiese studies en die Bybelwetenskap, om lewensomstandighede te kan verbeter. Dít kan die "natuurwetenskap" nie self bereik nie. Dit is mense wat in hutte leef of hulle in benadeelde plattelandse of in "informele" stedelike behuisingsomstandighede bevind. Voorts bestaan die sosiale wêreld nie sonder die dialektiese interaksie met 'n simboliese "canopy" nie. Daarom behoort ook die geestes- en sosiale wetenskappe deur die teologie verryk te word, veral in Afrika waar die inwoners as holistiese, spirituele sosiale wesens leef. 
Postmoderne epistemologie, eerder as die moderne of pre-moderne wyses van ken, bied 'n toepaslike toegang tot die diverse kompleksiteite van realiteite in die Afrika-konteks, 'n wêreld wat ons ervaar op die wyse waarop ons dit ontmoet - 'n wêreld wat is soos dit is as gevolg van "postkolonialisme".

Rondom die 1930's het kolonies en voormalige kolonies van Europese moondhede bykans 84.6\% van die wêreld uitgemaak (Fieldhouse 1989:373). Vandag lyk die situasie drasties anders. Kolonialisme is deur "neokolonialisme" vervang. Dit is die verskynsel waarvolgens voormalige koloniale moondhede steeds mag oor hulle voormalige politieke slagoffers uitoefen, maar wel nou deur middel van die wêreldekonomie en 'n militêre en kulturele meerderwaardigheid, en waarvan die verskyning van nuwe imperiale moondhede, soos byvoorbeeld die Verenigde State van Amerika, ook deel uitmaak (vgl Ashcroft, Griffiths \& Tiffin 1998:162-163). Na die Tweede Wêreldoorlog het historici begin om die term "postkoloniaal" te gebruik om na die "postkoloniale nasiestaat" (Ashcroft, Griffiths \& Tiffin 1998:186) te verwys. Hierdie term het ook inslag gevind in die werk van literêre kritici ${ }^{5}$, waarna die gebruik van die uitdrukking "postkoloniale studies" tot omtrent die 1990's algemeen voorgekom het (Moore 2000:182). ${ }^{6}$

Die term "postmodernisme" (vgl Schrag 1997:69-74, 129; Van Huyssteen 1999:137-139) en die konsep "postkoloniaal" kan albei ambivalent wees. Hulle verwys óf na 'n totale chronologiese en ideologiese breuk met die vorige paradigma, óf hulle verteenwoordig ' $n$ kritiese dialoog met daardie paradigma. Die koppelteken in "post-koloniaal" kan 'n aanduiding wees van die naïwiteit om so 'n totale breuk as vanselfsprekend te wil ag. Die term postkoloniaal, sonder die koppelteken, kan dui op die komplekse verhoudings tussen oorheersing en onderdanigheid, afhanklikheid en onafhanklikheid, begeerte en afkeer, weerstand en sameswering - wat die wisselwerking tussen die koloniseerder en die gekoloniseerde, gedurende die koloniale besetting en ook ná amptelike dekolonisasie, kenmerk (Moore 2000:182).

Nóg postmodernisme, nóg postkolonialisme verteenwoordig 'n metode om tekste te interpreteer. Die postkoloniale benadering, as verteenwoordigend van postmoderne epistemologie, impliseer egter wel 'n dekonstruktiewe benadering tot die hermeneutiek (Ashcroft, Griffiths \& Tiffin 1998:192-193). Hierdie referaat het ten doel om die siening dat postkoloniale hermeneutiek as 'n produk van postmoderne epistemologie beskou behoort te word, te belig. As deel van die huidige NRF-program "om die toekoms te ontsluit," kan dit as 'n relevante fokuspunt vir toekomstige navorsing beskou word. Die artikel bestaan uit vyf "preludes" wat ' $n$ inleiding tot postmoderne 


\section{Postmoderne epistemologie en postkoloniale hermeneutiek}

epistemologie, postkoloniale hermeneutiek en postkoloniale Bybelwetenskap bied en wat potensiële Bybelwetenskaplike navorsing in Suid-Afrika ontsluit.

\section{INLEIDING TOT POSTMODERNE EPISTEMOLOGIE}

Sedert die ontstaan daarvan in die sewentiende eeu verwys die term hermeneutiek na die wetenskap of kuns wat besin oor teorieë van interpretasie en kommunikasie (Grondin [1991] 1994:1). Vanaf die Verligting in Europese konteks het die interpretasie van antieke tekste gefokus op die ondersoek van die tradisies agter diskoerse (die historiese kritiek as eksegetiese benadering) of op die verhoudings tussen linguïstiese en literêre patrone binne diskoerse (die strukturalisme as eksegetiese benadering). Binne die spektrum van hedendaagse hermeneutiek is die uitdrukking "hermeneutiek van agterdog" kenmerkend van 'n strategie van interpretasie wat die sogenaamde "onmiddellike betekenis" van literêre kommunikasie wantrou, omdat die interpreteerder die moontlikheid van 'n "onbewuste magswil" by die kommunikeerder vermoed. ${ }^{7}$ Die hermeneutiek van suspisie het dus 'n emansiperende doelwit.

Volgens die feministeoloog, Elisabeth Schüssler Fiorenza (1999:51), kan 'n postmoderne weergawe van die hermeneutiek van agterdog verstaan word as 'n dekonstruktiewe ondersoekende praktyk wat praktyke van oorheersing denaturaliseer en demistifiseer. Dit verskil van die praktyk wat op 'n histories-kritiese wyse besig is om die lae van "kulturele sediment", wat ' $n$ "dieper waarheid" versteek of onderdruk, stelselmatig af te skil. Dekonstruksie maak 'n hele aantal metodes om met die teks te handel, moontlik. As eksponent van 'n multidimensionele benadering tot die eksegese van Bybeltekste gee Schlüsser Fiorenza (1999:26) spesifiek aandag in die interpretatiewe proses aan "eties-politieke" en "religieus-teologiese" vraagstukke.

In die post-Verligtingsituasie waarin ons ons bevind, kan ' $n$ mens egter nie werklik aan die eis om histories te dink, ontkom nie. In die geval van talle antieke geskrifte met hulle folkloristiese oorspronge kan die evolusionêre manier waarop verskeie Bybelse dokumente ontstaan het, nie geïgnoreer word nie. Om sodanige tekste te verstaan, word 'n interpretasie geverg wat erns maak met die verskillende lae van kulturele neerslag (dit wil sê "kulturele sediment" - oftewel die chronologiese stratifikasie van strata). Hierdie formgeschichtliche en traditionsgeschichtliche insig is bepaald die erfenis van die moderne histories-kritiese wetenskap. As postmoderne interpreteerders sal ons egter daardie modernistiese interpretasies, wat as "objektief" aangebied word, met agterdog bejeën. Postmoderne interpretasie is agterdogtig oor die ideologiese belange wat verskuil kan lê in die tekste van 
die Bybel en hulle onderskeie strata, sowel as die ideologiese belange van interpreteerders.

Postmoderne interpretasie put daarom uit die erfenis van Wilhelm Dilthey (1844-1911) wat nie die historistiese aanname aanvaar het dat 'n antieke teks slegs van historiese betekenis is en dat hierdie betekenis tot die verlede beperk is nie. Betekenis kan agterna weer beleef word, dit wil sê 'n Nach-erleben van 'n oorspronklike Erlebnis (ervaringsbelewenis). ${ }^{8}$ Die Nacherleben is egter nie identies met die oorspronklike belewing nie. Diegene wat "verstaan", kan hulleself wel op 'n manier in die oorspronklike situasie verplaas, maar hulle kan hulle nooit van hulle eie konteks losmaak nie omdat verstaan vanuit die perspektief vanuit die eie konteks geskied. Verstaan is daarom nie 'n blote herhaling van die oorspronklike "grammatiese betekenis" van tekste nie.

Wat die "teologiese verstaan" van die Bybel betref, lei die verstaan van die "grammatiese betekenis" van 'n geloofsgetuienis uit die verlede tot geloofsbelydenis in die hede as daar 'n kongenialiteit tussen teks en hermeneut bewerk word (Friedrich Schleiermacher). Interpretasie van die Bybel is dus teologiese eksegese omdat 'n "hermeneutiese sirkel" voltrek en die Woord van God as objek van ondersoek die subjektiewe appèl aan die interpreteerder word (Karl Barth). Sodoende vind daar 'n versmelting van horisonne (Hans-Georg Gadamer) tussen interpreteerder en die Woord van God plaas, oftewel 'n oorbrugging van 'n hermeneutiese boog (Paul Ricoeur). ${ }^{9}$ Dit is op hierdie punt dat postmoderne hermeneutiek 'n beslissende wending neem deur dié "hermeneutiese boog" nie meer voor te stel as dié tussen Bybel as "objek" en die hermeneut as "subjek" nie, maar as die simmetriese interaksie tussen "subjek" en "subjek" (Jürgen Habermas). ${ }^{10}$

Die moderne hermeneutiese benadering sien die teks vanuit die tradisionele perspektief van die rolleverwisseling tussen "subjek" en "objek". In terme van dié hermeneutiese sirkelbenadering verander die teks se status van "objek van ondersoek" na "subjek van bevraagtekening". Die interpreteerder word "objek" en van hom of haar word verwag om onvoorwaardelik en kritiekloos voor die ideologie van die teks en soms selfs voor die ideologie van die teks se kultuur te buig. Postmoderne historici beskou egter objektiwiteit as onbereikbaar en dus ' $n$ futiele onderneming wat uit die staanspoor vermy behoort te word. Enige interpretasie van 'n gebeurtenis in die verlede kan slegs maar rekening hou met 'n konglomeraat van leidrade uit die verlede en dit geskied met bepaalde aannames uit die hede oor die verlede. Waarna postmoderne historici streef, is om die kulturele strominge in die wêreld van die teks te verstaan, met ander woorde om die teks binne-in en as deel van 'n wyer kulturele en literêre konteks te verstaan en om eerlik omtrent die interpreteerder se eie konstruksies te wees (vgl 


\section{Postmoderne epistemologie en postkoloniale hermeneutiek}

Adam 1995:46-47). Postmoderne denke ontbloot dat manipulerende en opponerende idees - meesternarratiewe en kontranarratiewe - in dieselfde teks aangebied kan word, dat tradisie-bevestigende en ongewilde of selfs onkonvensionele idees deur skrywers gekommunikeer kon wees - met ander woorde dat skrywers met baie spesifieke ideologiese doelwitte voor oë geskryf het.

Hoe "ideologie" verstaan word, sal bepaal watter rigting sodanige "ideologiese kritiek" inslaan. Adam (1995:47-51) dui drie moontlikhede aan. Die eerste is die Marxistiese definisie van ideologie wat gebaseer is op die idee dat onderdrukking deur die onderdruktes gesien word as die manier hoe dinge maar daarna uitsien. Die onregverdigheid daarvan word op grond van gekondisioneerdheid nie ingesien nie, omdat dit gerasionaliseer word in terme van geïnstitusionaliseerde konvensies en die onbevraagtekende "manier hoe dinge is". Karl Marx beskryf dit as "valse bewussyn" (kyk Williams 1977; Eagleton 1976:11-43; 1983). Die tweede definisie van "ideologie" is 'n ietwat vae en algemene een. In so 'n definisie word "ideologie" gelyk gestel aan terme soos "politieke agenda", of selfs "opinie" of "oortuiging". 'n Derde moontlikheid is dat "ideologie" gedefinieer word as 'n beskrywing van daardie sosiale interaksies wat "betekenis" aan ons gedrag toeken. So gesien, word die verskynsel dat ons uit eie ondervinding betekenis aan sekere dinge heg, nie toegeskryf aan ons inherente vermoë of wilsbesluit nie. Dit word eerder gesien as die onbewustelike sameloop van sosiaal daargestelde aannames dit wil sê ons gekondisioneerdheid (vgl Adam 1995:48).

Interpreteerders van die Bybel wat gebruik maak van ideologiese kritiek, doen dit meestal vanuit óf die perspektief van 'n "valse bewussyn" óf vanuit die perspektief van die sosiale daarstelling van betekenis.

Eersgenoemde benadering sien die Bybelse teks as die produk van dominante groepe en hulle belange. Twee voorbeelde van hierdie benadering tot ideologiese kritiek is die feministiese kritiek op patriargale ideologie (kyk Schüssler Fiorenza 1985:1-17) en ideologiese kritici se fokus op die sosiale, politieke en ekonomiese situasie waarbinne Bybelse tekste geskryf is om sodoende lig te werp op manipulerende ideologieë en belange.

In 'n onlangse werk, Rhetoric and ethic: The politics of biblical studies (1999), verwys Schlüsser Fiorenza na die tradisionele histories-kritiese en strukturalistiese eksegetiese benaderings as interpretasies wat aanspraak op "wetenskaplikheid" maak omdat dit na bewering "objektiewe" resultate sou lewer en sprekend is van 'n "gedepolitiseerde etos". Wat in werklikheid gebeur, is dat só 'n toepassing van die tradisionele histories- en literêr-kritiese eksegese lesers van die Bybel as antieke tekste distansieer (Schüssler Fiorenza 1999:26-27). Teks en leser word gerelativeer. Hierdie relativering lei 
daartoe dat nie alleen die betekenis van die tekste en die relevansie van hulle histories-simboliese wêrelde tot die verlede beperk word nie, maar ook dat ons as interpreteerders self gerelativeer word omdat ons in die hede nie by die tekste vanuit die verlede eksistensieel betrokke raak nie. Outentieke eksistensie is om as gelowiges (wat betekenisvol in verhouding met God op grond van die genade van God lewe) betekenis te vind en te gee in en aan alle ander verhoudings van ons lewe. Hierdie totaliteit van ons lewe sluit die eties-sosiale dimensies in. Dit geld van ons as lesers van die Bybel in die hede en van die skrywers van die Bybel in die verlede en van die geloofsgetuies waarna hulle in hulle tekste verwys.

Om erns te maak met die eties-sosiaal-politieke dimensies van die Bybelse teks in terme van die Bybel se historiese kontekste, verg volgens Schlüssler Fiorenza 'n herkonseptualisering van Bybelwetenskaplike studies in multidissiplinêre "retoriese", eerder as sogenaamde objektiewe "wetenskaplike" terme. 'n Retoriese lees van die teks in hierdie sin van die woord is om bewustelik ruimte te skep vir die eksegeet om met meerdimensionele perspektiewe vrae aan die teks te stel - vrae wat voortspruit uit 'n hermeneutiese betrokkenheid by die (sosiale en simboliese) wêreld van die leser en die teks. Sodanige multidissiplinêre benadering verskaf 'n navorsingsraamwerk, nie alleen vir die integrasie van historiese, argeologiese, sosiologiese, literêre en teologiese benaderings as 'n "perspektiwistiese" lees van tekste nie, maar ook om teologies-eties-sosiaalpolitieke vrae as deel van die interpretatiewe proses aan die orde te stel.

Resultate van hierdie tipe eksegese van die Bybel toon dat tekste wat dateer uit die tyd toe Israel van 'n konfederasie van stamme na 'n monargale staat verander het, kenmerkende tekens van "oorgang" toon - tekens van óf die dominante sosiale klas se pogings om die nuutgevonde gesentraliseerde mag te legitimeer in die vorm van "meesternarratiewe", óf die gemarginaliseerde groepe se weerstand teen die nuwe magstruktuur in die vorm van "kontranarratiewe" (vgl Breytenbach 1997a, 1997b). Vanuit die perspektief van die kerk is die evangelie van Jesus Christus een van die opvallendste kontranarratiewe wat in die Bybel aangetref kan word (kyk Van Aarde 2001). Aangesien die dominante sosiale klasse in 'n posisie was om tekste te promulgeer en te bewaar, kan heelwat in die Bybel gevind word wat die onderdrukker se belange dien (Adam 1995:50). Twee voorbeelde van sosiale verskynsels wat in die Bybel voorkom (en deur die ideologie van die teks se kultuur bevorder word, maar nie rym met Jesus van Nasaret se boodskap en visie nie) is die opvatting in die Pastorale briewe oor die gesagsposisies van "kerklike ampte" wat gepaard gaan met 'n verwronge aanspraak op gesag en die onderwerping van vroue (kyk 1 Tim 2:9-15; Tit 


\section{Postmoderne epistemologie en postkoloniale hermeneutiek}

2:5). Ideologiese kritiek toon aan hoe die vorming en interpretasie van tekste deur sosiale, politieke en materiële omstandighede beïnvloed word.

Volgens Schüssler Fiorenza (1999:54) daag 'n kritiese retoriese proses van interpretasie die lesers van die Bybel uit om meer "teo-eties" gesofistikeerde lesers te word deur sosio-politieke lokaliteite en funksies in globale strukture van oorheersing te identifiseer en te problematiseer. Ideologiese kritici toon aan hoe die wyses waarop oorheersergroepe die Bybel benader en interpreteer, onderdrukkende sosiale verhoudings kan voortsit. Kontranarratiewe in die teks kan aan die lig gebring word om hierdie tendens teen te werk. Dit verg egter ander benaderings tot interpretasie as die tradisionele benaderings (kyk Adam 1995:54). Betrokke hermeneutiek sal dus taal as 'n instrument van mag en ideologie ontbloot, eerder as om dit slegs as beskrywend of kommunikatief te analiseer (Schüssler Fiorenza 1999:60).

Postmoderne denke kan, tot die mate dat dit oordeel dat absolute, objektiewe waarhede wensdenke is en dat die premisse waarop waarheidsaansprake gefundeer word, nooit as die enkel en enigste vertrekpunt beskou behoort te word nie (kyk Adam 1995:5), as antifundasioneel ("foundational") geag word. Dit is ook anti-totaliserend ("antitotalizing") tot die mate dat dit oordeel dat geen teorie die volle en algehele antwoord kan bied op vrae wat gestel word nie. Inligting wat 'n teorie weerspreek of wat ' $n$ ander teoretiese hoek moontlik maak, kan altyd na vore kom. As ' $n$ teorie die aanspraak maak dat dit "totaal" is, beteken dit in effek dat ander moontlikhede wat bestaan, gewoon oorgesien is of dat kriteria ontwerp is om die moontlikhede uit te skakel. Postmoderne denke is ook demistiferend ("demystifying") in die sin dat dit die veronderstellings dat sekere dinge "natuurlik" en ander dinge "bo-natuurlik" is, bevraagteken. Dit gebeur wanneer ingesien word dat sosiale gekondisioneerdheid as algemeenaanvaarde waardes deur byvoorbeeld God of die Bybel gelegitimeer sou wees - soos byvoorbeeld die onderdanigheid van vroue in patriargaal georïenteerde huwelike of homoseksuele relasies as voor die voet "teennatuurlik". Postmoderniteit ontbloot dat sulke aannames dikwels manipulerende, eksploiterende en diskriminererende ideologiese motiewe verbloem. Net so kan partikuliere ekonomiese of politieke belange deur aansprake op universaliteit of noodsaaklikheid gekamoefleer word (Adam 1995:5, 11).

Dit is egter nie net postmoderniste wat demistifikasie bedryf nie. Daar is filosowe en teoloë wat reeds in die moderne periode dieselfde gedoen het. Die so genoemde "hermeneutiek van agterdog" kan as voorbeeld dien. Demistiferende agterdog is egter slegs op ' $n$ beperkte skaal deur moderniste en wel slegs ten opsigte van sekere gebiede toegepas, terwyl ander gebiede 
bo verdenking gebly het. Die verskil tussen moderne demistifering en die postmoderne weergawe daarvan is dat laasgenoemde die "agente" van demistifikasie ook demistifiseer. Dit sluit veral die rede self in asook wetenskap as sodanig, maar ook die hoog aangeprese liberale demokrasie. Hierdie drie begrippe is waarskynlik van die belangrikste onderwerpe van die postmoderne ondersoek self. Deur die aannames van hierdie begrippe te demistifeer, is kritici besig om die moderne praktyk ideologies-krities teen sigself te draai - en dit is waarin die "postmoderniteit" van postmoderne demistifering geleë is (Adam 1995:12). 'n Postmoderne weergawe van demistifering kom neer op "permanente kritiek" en self-refleksiewe (dit wil sê introspektiewe) kritiek wat daarop gerig is om onvoorwaardelik alle vorme van onaanvaarbare dominansie aan die kaak te stel (vgl McKerrow 1999:441).

Postmoderne dekonstruksie is die verwesenliking van die gedagte van antifoundationalism in praktyk. Niks mag as onaantasbaar beskou word bloot omdat dit deur byvoorbeeld ' $n$ instelling gelegitimeer is nie. Daar kan geen absolute en gesaghebbende vertrekpunt vir interpretasie wees nie en dit sluit die interpretasie van die Bybel in. Volgens hierdie denkwyse kan nóg die teks, nóg die skrywer of die betekenis, nóg die historiese gebeurtenis of enige ander self-geïdentifiseerde gesag as sodanige vertrekpunt aanvaar word nie (Adam 1995:31). Dit is moontlik dat daar binne 'n "gesaghebbende" teks as meesternarratief gemarginaliseerde stemme tussen die lyne hoorbaar is of dat kontranarratiewe geïdentifiseer kan word (kyk Lyotard 1984:xxiv; cf 1993).

Postmoderne denke dekonstrueer ook die binêre opposisies wat algemeen in strukturalisme voorkom deur aan te toon hoe die "bevoorregte" lid in die opposisionele paar van die ander lid afhanklik is, en hoe die keuse om twee aspekte teenoor mekaar te stel reeds meerderwaardigheid en minderwaardigheid impliseer (Edgar \& Sedgwick 2002:231).

\section{INLEIDING TOT POSTKOLONIALE HERMENEUTIEK}

Volgens Fernando Segovia (1998:51 nota 3), besin postkoloniale studies breedweg oor die diskoers en praktyk van imperialisme en kolonialisme vanuit die posisie waarby imperialisme en kolonialisme - tot 'n groot mate, maar nie volkome nie - formeel geëindig het, terwyl dit steeds in praktyk as neoimperialisme en neokolonialisme manifesteer. Binne die spektrum van postmoderne hermeneutiek van agterdog bevraagteken postkoloniale teorieë bevoorregting en mag, weier dit om die meerderwaardigheid van westerse kulture te erken, en poog dit om perspektiewe en gedrag ten gunste van groter gelykheid tussen mense te verander. Hierdie tipe aangeleenthede is voorheen binne die fokusgebiede van die politiek, die historiografie van derde 


\section{Postmoderne epistemologie en postkoloniale hermeneutiek}

wêreld-gemeenskappe, die posisie van vroue, ekonomiese ontwikkeling binne 'n globale konteks, ekologie en sosiale onregverdigheid, bestudeer.

Koloniale en imperiale oorheersing is deur antropologiese (en teologies-ideologiese) teorieë gelegitimeer. Sodoende is gekolonialiseerde lande en hulle inwoners op dieselfde manier as vroue en kinders in patriargale gemeenskappe as minderwaardig geag. Om hierdie rede sou gekoloniseerdes dan nie in staat wees om na hulleself om te sien nie, alhoewel hulle dit voor kolonisasie wel reggekry het. Derhalwe het hulle die toesig van die Weste nodig. Hierdie paternalisme gee uiteraard voor om tot die voordeel van die "ontwikkelende" mense te strek (vgl Young 2003:2). Hierteenoor dring postkoloniale studies aan op die reg van alle mense om 'n materiële en kultureel outentieke bestaan te voer. Postkoloniale bewustheid beteken dat die ervaring van Andere vanuit hulle eie perspektief ernstig opgeneem sal word. Interaksie en kommunikasie sal simmetries wees en sal nie van bo-af geskied nie (vgl Gandhi 1998:39-40). Young (2003:4-5) verwoord hierdie bewustheid soos volg:
A simple analogy would be with feminism, which has involved a comparable kind of project: there was a time when any book you might read, any speech you might hear, any film that you saw, was always told from the point of view of the male. The woman was there, but she was always an object, never a subject. From what one would read, or the films you would see, the woman was always looked at. She was never the observing eye.

As 'n "alternatiewe hermeneutiek" interpreteer postkolonialisme tekste deur tekens in tekste te identifiseer wat dui op die aanwesigheid van gemarginaliseerde "gekoloniseerdes". Hierdie "tekens" word gevind deur te let op literêre "gapings" en "stiltes" in dokumente en dit vanuit plekke wat van "diasporisering" getuig, te lees (vgl Sugirtharajah 1998:16, 18). Postkoloniale hermeneutiek fokus dus op linguïstiese, kulturele en geografiese oordrag. Dit gaan uit van die standpunt dat daar 'n verband tussen vertaling en postkolonialisme bestaan (Young 2003:138). Om te vertaal beteken "om oor te dra". 'n Kolonie begin ook as 'n "vertaling". Die "oorspronklike" word oor die aardbol na 'n ander plek oorgedra waar 'n weergawe daarvan gevestig word, soos New England, New Spain, New Amsterdam. Hierdie verafgeleë reproduksie verskil egter uiteraard van die oorspronklike. Daarom is 'n kolonie ook soos 'n metafoor: die "oorspronklike" word deur die "beeld" verplaas. Net soos in metaforiek is dié verplasing nie net óf 'n negatiewe óf 'n positiewe verskynsel nie. Postkoloniale analise fokus daarom op sowel die positiewe as die negatiewe veranderings wat plaasgevind het. 
Om van een taal na 'n ander te vertaal, bring 'n algehele verandering van die materiële vorm teweeg. Wanneer die inheemse kultuur ondergeskik aan die kultuur van die koloniale moondheid gestel word, vind 'n transformasie van alle aspekte van die oorspronklike kultuur plaas.

Terselfdertyd is dit so dat sekere aspekte van die oorspronklike kultuur nie vertaal kan word nie. Vertaling is nooit 'n totaal neutrale vorm van simmetriese interkulturele kommunikasie nie. Magsverhoudings, en derhalwe ook politieke kwessies, is altyd betrokke. Een party doen die vertaling, terwyl die ander 'n meer passiewe posisie, naamlik om vertaal of getransformeer te word, inneem. Dit is inderdaad die posisie waarin die gekoloniseerde persoon hom of haar bevind.

Verandering word in terme van verbetering of verslegting gesien. Die koloniale weergawe word as "beter" as die oorspronklik inheemse beskou. Dít wat in die oorspronklik inheemse as onaanvaarbaar gereken is, word in die weergawe verbeter. Die koloniale taal word magtiger as die inheemse taal. Dit het in 'n vroeë stadium van kolonisasie daartoe gelei dat die inheemse tale se orale tekste vertaal en in vasgestelde geskrewe tekste omskep is. Op die wyse word vertaling 'n manier waarop beheer verkry word oor die taal, kultuur en die mense wat vertaal word. Inheemse mense se gebiede is nie alleen oorgeneem nie, maar is ook hernoem, hertoegeken en geherstruktureer (Young 2003:140).

\section{INLEIDING TOT POSTKOLONIALE BYBEL- INTERPRETASIE}

Binne die raamwerk van die Bybelwetenskap verken postkolonialisme strategieë om tekste vanaf die posisie van "minderhede", wat in 'n nuwe "bevryde" konteks geakkommodeer is, maar wat hulleself as beide daarby ingesluit en daarby uitgesluit bevind, te interpreteer. Die tekste van die Bybel word beskou as die "historiese" produkte van mense wat onderwerp was aan die uitbuiting van Midde-Oosterse en Grieks-Romeinse supermoondhede en wat vandag in die derde wêreld deur mense, wat op hulle beurt onderworpe was aan moderne koloniale magte, geïnterpreteer word. Soortgelyk aan talle Bybelkarakters en die oorspronklike teikengehore, word die boorlinge in die postkoloniale derde wêreld in 'n nuwe konteks geakkommodeer, maar hulle bevind hulleself sowel daarby ingesluit as daarvan uitgesluit. Hulle "identiteit" is nie maar slegs 'n kwessie van 'n dubbel bewussyn, as sou die boorlinge nie weet wie hulle is nie. Hulle situasie is eerder een van permanente ontwrigting. Gekoloniseerdes kan nie na hulle voormalige posisie terugkeer nie, maar kan ook nooit ten volle met die nuwe situasie geïntegreer word nie. Hulle bevind hulle in 'n kultuur wat hulle akkommodeer, maar wat tegelykertyd op diegene 


\section{Postmoderne epistemologie en postkoloniale hermeneutiek}

wat geakkommodeer is, neersien. Waarop dit neerkom, is dat ' $n$ identiteit van eendersheid en andersheid, van inpas en nie inpas nie, aangeneem word.

Sedert die laat 1990's het postkoloniale studies 'n beduidende invloed op die Bybelwetenskap gehad (kyk Moore 2000:184-188). In 1996 het 'n uitgawe van die vaktydskrif Semeia ('n "eksperimentele" vaktydskrif vir Bybelwetenskaplike studies) met die titel Postcolonialism and scriptural reading verskyn (kyk Donaldson 1996; vgl Gallagher 1994). Tussen 1998 en 2000 is 'n redaksie-bundel, The postcolonial Bible gepubliseer. ${ }^{11}$ 'n Monograaf deur R S Sugirtharajah (1998b): Asian biblical hermeneutics and postcolonialism is in dieselfde jaar gepubliseer en sy boek The Bible in the Third World het in 2001 verskyn. In 1999 het die Journal for the Study of the New Testament 'n uitgawe met die tema, Postcolonial perspectives on the New Testament and its interpretation (onder redaksie van Sugirtharajah 1999) uitgegee. In die volgende uitgawe van hierdie vaktydskrif het vier resensies oor The postcolonial Bible verskyn. In 2000 het die vaktydskrif Biblical Interpretation die interpretasie van die Bybel in postkoloniale Hong Kong bespreek. The postcolonial Bible commentary, ook onder redaksie van Sugirtharajah en geskoei op die lees van The women's Bible commentary, word tans voorberei. In 2000 is 'n nuwe navorsingseenheid genaamd "New Testament Studies and Postcolonial Studies" binne die Society of Biblical Literature gestig. Daar het dus heelparty publikasies binne die kort tydsbestek van net meer as 'n dekade, die lig gesien. ${ }^{12}$

\section{ONTSLUITING VAN DIE TOEKOMS: 'N INLEIDING TOT POSTKOLONIALE STUDIES IN SUID-AFRIKA}

In Suid-Afrika het Professor Jeremy Punt, ${ }^{13}$ voorheen van die Universiteit van Fort Hare en vanaf 2004 'n Nuwe-Testamentikus aan die Universiteit van Stellenbosch, postkoloniale studies aan die werkgemeenskap van NuweTestamentici bekend gestel (vgl ook West 2001; England 2004) ${ }^{14}$ Nagraadse studente aan die Universiteit van Pretoria is onder my leiding besig met verhandelings oor verskillende aspekte van postkoloniale hermeneutiek. Dit sou egter op hegemonie neerkom sou daar die verwagting wees dat Bybelwetenskap in Suid-Afrika in die geheel in postkoloniale studies omskep behoort te word.

Wat wel verwag kan word is dat teologiese opleiding en teologiese/Bybelse hermeneutiek die teologiese gemeenskap, teologiese studente en die algemene publiek meer bewus sal maak van die heuristiese belangrikheid van postmoderne epistemologie en postkoloniale hermeneutiek. 
Eksegete behoort hulle eie-belang, maar ook dié van ander en van belangegroepe in die Bybel, te identifiseer. In terme van narratiewe pastorale modelle behoort teologiese studente opgelei te word om luisteraars, vertellers, interpreteerders en vertalers van Bybelse narratiewe te wees, terwyl hulle terselfdertyd ook na die narratiewe van Ander luister. Hulle hermeneutiese betrokkenheid by die diversiteit van die geloofsgetuienisse in die Bybel sal hulle in staat stel om mense binne sowel as buite die Christelike geloofsgemeenskap volgens die waardes van Jesus se boodskap en met empatie te lei. Dit vereis navorsing oor kerklike én publieke teologie, 'n sensitiwiteit vir mense binne die elitistiese teologiese gilde sowel as vir diegene in ander geloofsgemeenskappe en in die gesekulariseerde omgewing. Dit vra die erkenning dat 'n paradigma van multi-en interdissiplinêre teologiese en Bybelwetenskaplike navorsing reeds aangebreek het.

Die kritieke vraag, naamlik of postkoloniale studies werklik vir die Bybelwetenskap relevant is, kan egter wel gevra word. Dit is immers so dat die koloniale geskiedenis in die moderne tydvak begin het toe Europese magte begin het om die nie-Europese wêreld te koloniseer. Pre-moderne imperiale ondernemings het wel ook daartoe gelei dat die veroweraar minerale regte en ander vorme van welvaart van die oorwonne volkere bekom het. Volgens Stephen Moore (2000:185), het Europese kolonisasie daarenteen 'n veel groter impak op inheemse volkere en hulle landsgebiede gehad. Die ekonomie is geherstruktureer ten einde 'n konstante vloei van menslike en natuurlike hulpbronne, soos byvoorbeeld slawe, setlaars en grondstowwe, tot voordeel van die koloniseerder, te verseker (Moore 2000:185; cf Loomba 1995:3-4).

Alhoewel kolonialisme ongekende vlakke in die moderne geskiedenis bereik het, het vroeëre politieke magte, veral die antieke ryke van die Nabye Ooste, asook oos- en wes-Mediterreense ryke, "kolonisasie" bedryf (Moore 2000:185). In onlangse werke van die Nuwe-Testamentikus van Boston, Richard Horsley (2003), naamlik Religion and Empire en Jesus and Empire, word 'n ooreenkoms tussen die ongelukkige gebeure van "11 September" en die Verenigde State van Amerika en Groot Brittanje se invalle in Afghanistan en in Irak, en die Romeinse imperiale besettings van Palestina in die eerste eeu CE, getref (vgl also Horsley 2003d). Postkoloniale studies bevat daarom 'n "vertaalprobleem" vir studente van die antieke letterkunde (vgl Gallagher 1996:230-233) - dit is tot 'n groot mate dieselfde probleem wat kontemporêre postmoderne teorieë vir die "gebruiker" van die Bybel inhou. Dit is nie nodig nie - en dit sou inderdaad ook onverantwoordelik wees - om hierdie teorieë af 


\section{Postmoderne epistemologie en postkoloniale hermeneutiek}

te maak vanweë postmoderniteit se dialoog met modernisme, eerder as met pre-moderniteit.

Aangesien die postkoloniale hermeneutiek op 'n interkulturele wyse op die kultuurdinamika van mense in Bybelse tye en op die kultuur van mense in die postkoloniale derde wêreld fokus, is die hermeneutiese "dwaling van etnosentrisme" egter 'n wesentlike gevaar. Die dwaling is daarin geleë dat verskille onder kulture nie na behore onderskei word nie. ${ }^{15}$ Sodanige onderskeid funksioneer op 'n sinchroniese, sowel as 'n diachroniese vlak. Met ander woorde, die sosiale dinamika van kulture binne dieselfde kontemporêre tydvak is nie noodwendig eenders nie. Dit geld tot 'n groter mate kulturele gemeenskappe van twee duisend jaar gelede. Postkoloniale Bybelwetenskaplike studies behoort daarmee rekening hou dat die Bybel meer as twee duisend jaar gelede in 'n homogene, landbougemeenskap ontstaan het, terwyl mense in die postkoloniale wêreld by aspekte van die geïndustrialiseerde wêrelddorp (global village) aangepas het. As hedendaagse eksegete moet ons nie dink dat ons die Bybel "wetenskaplik" interpreteer asof die industriële rewolusie niks aan ons patrone van sosiale persepsie verander het nie (Holmberg 1990:133; vgl Rohrbauch 1987:113). Eksegete kan derhalwe daarby baat om die eksegetiese insigte van die sosiaal-wetenskaplike kritiek van die Bybel, wat doelbewus poog om etnosentrisme te vermy (kyk onder andere Elliott 1993), by 'n metodologie wat met postmoderne teorieë en postkoloniale modelle van interpretasie korreleer, te integreer.

Voorts is postkoloniale studies hoegenaamd nie maar net gefokus op die verskynsel kolonialisme en postkolonialisme as 'n paar nie. Die fokus val ook op 'n reeks ander verwante verskynsels binne die sosiale en geesteswetenskappe:

- imperialisme,

- hibriditeit,

- patriargale bedelings,

- globalisasie/globalisering,

- ekspansionisme,

- herverdeling van grond,

- verset en opstand,

- terrorisme,

- nasionalisme,

- studie van die "subaltern",

- marginalisasie,

- migrasie, 
- die diaspora-verskynsel,

- dekolonisasie en

- neokolonialisme.

Al hierdie navorsingsterreine word deurkruis deur aspekte soos byvoorbeeld:

- die verskynsel taal,

- teorieë van vertaling,

- gender,

- ras,

- etnisiteit en

- klas.

Die relevansie van hierdie konsepte vir die interpretasie van Bybelse tekste, selfs in hulle antieke milieu gesien, is voor die hand liggend en dit geld die wêreld in die breë en ook Suid-Afrika in die besonder.

\section{Endnotas}

${ }^{1}$ Kyk bv Adam (1995, 2000a, 2000b); Moore \& Anderson (1992); Moore \& Jobling (1992); Moore (1992, 1994, 2000).

${ }^{2}$ Vgl Said (1993).

${ }^{3}$ Vgl Spivak $(1987,1990,1998)$.

${ }^{4}$ Kyk die tema van hierdie konferensie: "Shifting boundaries of knowledge - the role of social sciences, law and humanities".

${ }^{5}$ Kyk byvoorbeeld die werk van Robert J C Young (Oxford Universiteit), 'n leidende figuur in literatuurteorie en sosiale antropologie:

- $\quad 1987$, Post-structuralism and the question of history, onder redaksie van Derek Attridge, Geoff Bennington \& Robert Young. New York: Cambridge University Press.

- $\quad$ 1990, White mythologies: Writing history and the West. New York: Routledge.

- $\quad$ 1995, Colonial desire: Hybridity in theory, culture and race. London: Routledge.

- 1996, Torn halves: Political conflict in literary and cultural theory. Manchester: Manchester University Press.

- 2001, Postcolonialism: An historical introduction. Oxford: Blackwell.

- 2003, Postcolonialism: A very short introduction. Oxford: Oxford University Press.

${ }^{6}$ Die elektroniese katalogus van die biblioteek van die Universiteit van Pretoria toon 87 publikasies (wat nie artikels insluit nie) onder die soekwoord "postkoloniaal" aan.

${ }^{7}$ So genoem deur Paul Ricoeur (1970) wat Nietzsche, Freud en Marx as voorbeelde voorhou van diegene wat aansprake op betekenis gereduseer het tot "economy or energies that function behind them (impulses, class interests, will to power)" (Grondin 1994:15). 


\section{Postmoderne epistemologie en postkoloniale hermeneutiek}

${ }^{8}$ Wilhelm Dilthey se hermeneutiese besinning het 'n verset verteenwoordig teen die empiriese geskiedeniswetenskap wat historiese verskynsels op dieselfde wyse wil bestudeer het as wat die natuurwetenskap met natuurverskynsels doen. Hierdie benadering sien die geskiedenis bloot as oorsaak en gevolg en het nie 'n oog vir die eiesoortigheid van historiese verskynsels nie. Hierteenoor het Dilthey 'n geskiedeniswetenskap beoog wat met die eiesoortige sou rekening hou, en dit wou hy bewerkstellig met 'n kritiek van die historiese rede. Historiese verskynsels en die menslike synswyse word volgens Dilthey nie wetmatig bepaal nie maar is ' $n$ onafgehandelde, onvoorspelbare wordingsproses in die tyd. Hierdie synswyse noem hy lewe, maar dan as geestelike skeppingsdrang en -krag en nie as biologiese proses nie. Dit gaan om belewenisse (Erlebnisse) waardeur mense vir hulleself uitmaak wat die betekenis van hulle bestaan is. Belewenisse dring steeds om tot uiting te kom in uiterlike gestaltes. Dit is kultuurprodukte in onderskeiding van natuurprosesse en as kultuurprodukte is dit sindraers wat duursaam is en daarom nie net toeganklik vir tydgenote nie, maar ook vir mense van later tye. Wilhelm Dilthey se hermeneutiese besinning het 'n verset verteenwoordig teen die empiriese geskiedeniswetenskap wat historiese verskynsels op dieselfde wyse wil bestudeer het as wat die natuurwetenskap met natuurverskynsels doen. Hierdie benadering sien die geskiedenis bloot as oorsaak en gevolg en het nie ' $n$ oog vir die eiesoortigheid van historiese verskynsels nie. Hierteenoor het Dilthey 'n geskiedeniswetenskap beoog wat met die eiesoortige sou rekening hou, en dit wou hy bewerkstellig met ' $n$ kritiek van die historiese rede. Historiese verskynsels en die menslike synswyse word volgens Dilthey nie wetmatig bepaal nie maar is 'n onafgehandelde, onvoorspelbare wordingsproses in die tyd. Hierdie synswyse noem hy lewe, maar dan as geestelike skeppingsdrang en -krag en nie as biologiese proses nie. Dit gaan om belewenisse (Erlebnisse) waardeur mense vir hulleself uitmaak wat die betekenis van hulle bestaan is. Belewenisse dring steeds om tot uiting te kom in uiterlike gestaltes. Dit is kultuurprodukte in onderskeiding van natuurprosesse en as kultuurprodukte is dit sindraers wat duursaam is en daarom nie net toeganklik vir tydgenote nie, maar ook vir mense van later tye.

${ }^{9}$ Volgens Ricoeur is dit 'n proses van defigurasie $\left(\right.$ mimesis $\left.^{1}\right)$, konfigurasie (mimesis ${ }^{2}$ ) en refigurasie $\left(\right.$ mimesis $^{3}$ ) (kyk Simms 2003:94-98).

\footnotetext{
${ }^{10}$ Vir die bydraes van Schleiermacher, Dilthey, Bultmann, Barth, Gadamer, Ricoeur en
} Habermas, kyk Thiselton $(1980,1992)$.

${ }^{11}$ Die eerste twee volumes is in 1998 en 1999 onder redaksie van R S Sugirtharajah uitgegee en die derde volume is in 2000 onder redaksie van F F Segovia.

${ }^{12}$ Kyk onder andere Sugirtharajah (1991, 1996, 1998a, 1998b, 1998c, 1999, 2001), Horsley (1997, 1998, 2000, 2003a, 2003b, 2003c. 2003d), Carter (2000, 2001), en Segovia (19951, 1995b, 1998, 2000a, 2000b, 2000c).

${ }^{13}$ Jeremy Punt het die volgende artikels oor die onderwerp gepubliseer:

- 2001, The New Testament, theology and imperialism: Some postcolonial remarks on Beyond New Testament theology. Neotestamentica 35(1-2), 120-145.

- 2002a, From rewriting to rereading the Bible in postcolonial Africa: Considering the options and implications. Missionalia 30(3), 410-442.

- 2002b, Empire, Messiah and violence: A contemporary view. Scriptura 80, 259-274.

- 2002c, Towards a postcolonial reading of freedom in Paul, in Ukpong, J S et al (ed), The Bible in the global village: Cape Town, 125-149. Atlanta: Scholars Press (also: Leiden: Brill). (Global Perspectives on Biblical Scholarship Series 3.)

- 2003, Postcolonial biblical criticism in South Africa: Some mind and road mapping. Neotestamentica 37, 59-85.

- 2004, Whose Bible, yours or mine? Contested ownership and Bible translation in Southern Africa. HTS 60(1\&2), 307-328.

${ }^{14}$ Musa Dube van die Universiteit van Botswana is vanaf die vroegste toepassing daarvan op die Bybelwetenskap, by postkoloniale Bybelwetenskaplike studies betrokke (kyk Dube 1997, 1998, 2001). 
${ }^{15}$ Emile Durkheim (in Talmon 1978:324) stel dit soos volg: "Social facts are functions of the social system of which they are part; therefore they cannot be understood when they are detached. For this reason, two facts which come from two different societies cannot be fruitfully compared merely because they seem to resemble one another."

\section{Literatuurverwysings}

Adam, A K M 1995. What is postmodern biblical criticism? Minneapolis, MN: Fortress. (Guides to Biblical Scholarship.)

Adam, A K M (ed) 2000. Handbook of postmodern Biblical interpretation. St Louis, MO: Chalice Press.

Adam, A K M (ed) 2001. Postmodern interpretations of the Bible - A reader. St Louis, MO: Chalice Press.

Ashcroft, B, Griffiths, G \& Tiffin, H (eds) 1995. The post-colonial studies reader. London: Routledge.

Bhabha, H 1992. Postcolonial criticism, in Greenblatt, S \& Gunn, G (eds), Redrawing the boundaries. New York: Modern Language Association of America.

Bhabha, H (ed) 1994. The location of culture. London: Routledge.

Breytenbach, A P B 1997a. Die herfsfees en die koningsrite by Bet-El as interteks van Amos 7:10-8:14 en Hosea 9:1-9. HTS 53(3), 513-528.

Breytenbach, A P B 1997b. Meesternarratiewe, kontranarratiewe en kanonisering: 'n Perspektief op sommige profetiese geskrifte. HTS 53(4), 1157-1186.

Carter, W 2000. Matthew and the margins: A sociopolitical and religious reading. Maryknoll, NY: Orbis.

Carter, W 2001. Matthew and Empire: Initial explorations. Harrisburg, PA: Trinity Press International.

Donaldson, L (ed) 1996. Postcolonialism and scriptural reading. Semeia 75.

Dube, M W 1997. Towards a postcolonial feminist interpretation of the Bible. Semeia 78, 11-26.

Dube, M 1998. Savior of the world but not of this world: A postcolonial reading of spatial construction in John, in Sugirtharajah, R S (ed), The postcolonial Bible, 118-135. Sheffield: Sheffield Academic Press.

Dube, M W 2001. Divining Ruth for international relations, in Adam, A K M 2001, Postmodern interpretations of the Bible: A reader, 67-80. St Louis, MO: Chalice Press.

Eagleton, T 1976. Criticism and ideology: Study in Marxist literary theory. London: Verso.

Eagleton, T 1983. Literary theory. Minneapolis, MN: University of Minnesota Press.

Edgar, A \& Sedgwick, P 2002. Cultural theory: The key thinkers. London: Routledge. (Routledge Key Guides.)

England, F 2004. Mapping postcolonial biblical criticism in South Africa. Neotestamentica 38(1), 88-99.

Elliott, J H 1993. What is social-scientific criticism? Minneapolis, MN: Fortress. (Guides to Biblical Scholarship.)

Fieldhouse, D K 1989. The colonial empires. London: Macmillan.

Gallagher, S VanZanten (ed) 1994. Postcolonial literature and the biblical call for justice. Jackson, MA: University Press of Mississippi. 


\section{Postmoderne epistemologie en postkoloniale hermeneutiek}

Gallagher, S VanZanten 1996. Mapping the hybrid world: Three postcolonial motifs. Semeia 75:229-240.

Gandhi, L 1998. Postcolonial theory: A critical introduction. New York: Columbia University Press.

Grondin, J [1991] 1994. Introduction to philosophical hermeneutics. Foreword by H-G Gadamer and tr by J Weinsheimer. New Haven, CT: Yale University Press.

Holmberg, B 1990. Sociology and the New Testament: An appraisal. Minneapolis, MN: Fortress.

Horsley, R A (ed) 1997. Paul and Empire: Religion and power in Roman imperial society. Harrisburg, PA: Trinity Press International.

Horsley, R A 1998. Submerged biblical histories and imperial biblical studies, in Sugirtharajah, R S (ed), The postcolonial Bible: The Bible and postcolonialism, 1, 152-173. Sheffield: Sheffield Academic Press.

Horsley, R A (ed) 2000. Paul and politics: Ekklesia, Israel, imperium, interpretation. Essays in honor of Krister Stendahl. Harrisburg, PA: Trinity Press International.

Horsley, R A 2003a. Jesus and the Empire: The Kingdom of God and the new world disorder. Minneapolis, MN: Augsburg Fortress.

Horsley, R A 2003b. Religion and Empire: People, power, and the life of the Spirit. Minneapolis, MN: Fortress.

Horsley, R A 2003c. Feminist scholarship and postcolonial criticism: Subverting imperial discourse and reclaiming submerged histories, in Matthews, S, Briggs, Kittredge, C \& Johnson-Debaufre, M (eds), Walk in the ways of wisdom: Essays in honor of Elisabeth Schüssler Fiorenza, 297-317, Harrisburg, PA: Trinity Press International.

Horsley, R A 2003d. Religion and other products of Empire. Journal of the American Academy of Religion 71, 13-44.

Loomba, A 1998. Colonialism/Postcolonialism. London: Routledge.

Lyotard, J-F 1984. The postmodern condition, tr by G Bennington \& B Massumi. Minneapolis, MN: University of Minnesota Press. (Theory and History of Literature 10.)

Lyotard, J-F 1993. The postmodern explained, tr and ed by J Pefanis \& M Thomas. Minneapolis, MN: University of Minnesota Press.

McKerrow, R 1999. Contemporary rhetorical theory: A reader, in Lucaites, J L, Celeste, M C \& Sally, C (eds), Critical rhetoric: Theory and practice, 441-463. New York: Guilford Press.

Moore, S D \& Anderson, J C (eds) 1992. Mark \& method: New approaches in biblical studies. Minneapolis, MN: Fortress.

Moore, S D 1992. Mark and Luke in poststructural perspectives: Jesus begins to write. New Haven, $\mathrm{NH}$ : Yale University Press.

Moore, S D \& Jobling, D (eds) 1992. Poststructuralism as exegesis. Atlanta, GA: Society of Biblical Literature. (Semeia 54).

Moore, S D 1994. Poststructuralism and the New Testament: Derrida and Foucault at the foot of the cross. Minneapolis, MN: Fortress.

Moore, S D 2000. Postcolonialism, in Adam, A K M (ed), Handbook of postmodern Biblical interpretation, 182-188. St Louis, MO: Chalice Press. 
Punt, J 2001. The New Testament, theology and imperialism: Some postcolonial remarks on Beyond New Testament theology. Neotestamentica 35(1-2), 120145.

Punt, J 2002a. From rewriting to rereading the Bible in postcolonial Africa: Considering the options and implications. Missionalia 30(3), 410-442.

Punt, J 2002b. Empire, Messiah and violence: A contemporary view. Scriptura 80, 259-274.

Punt, J 2002c. Towards a postcolonial reading of freedom in Paul, in Ukpong, J S et al (ed), The Bible in the global village: Cape Town, 125-149. Atlanta, GA: Scholars Press (also: Leiden: Brill). (Global Perspectives on Biblical Scholarship Series 3.)

Punt, J 2003. Postcolonial biblical criticism in South Africa: Some mind and road mapping. Neotestamentica 37, 59-85.

Punt, J 2004. 2004, Who's Bible, yours or mine? Contested ownership and Bible translation in Southern Africa. HTS 60(1\&2), 307-328.

Ricoeur, P 1970. Freud and philosophy, translated by D Savage. New Haven, CN: Yale University Press.

Rohrbauch, R L 1984. Methodological considerations in the debate over the social class status of early Christians. Journal of the American Academy of Religion 52(3), 519-546.

Rohrbauch, R L 1987. "Social location of thought" as a heuristic construct in New Testament study. Journal for the Study of the New Testament 30, 103-119.

Said, E 1978. Orientalism: Western conceptions of the Orient. London: Penguin.

Said, E 1993. Culture and imperialism. New York, NY: Alfred A Knopf.

Schrag, C O 1997. The self after postmodernity. New Haven, CN: Yale University Press.

Schüssler Fiorenza, E 1985. De-centering Biblical interpretation. Journal of Biblical Literature 107, 1-17.

Schüssler Fiorenza, E 1999. Rhetoric and ethic: The politics of Biblical studies. Minneapolis, MN: Fortress.

Segovia, F F 1995a. Toward a hermeneutics of the Diaspora: A hermeneutics of Otherness and engagement, 57-74, in Segovia, F F \& Tolbert, M A (eds), Reading from this place, 1: Social location and biblical interpretation in global perspective, 57-74. Minneapolis, MN: Fortress.

Segovia, F F 1995b. Toward intercultural criticism: A reading strategy from the Diaspora, in Segovia, F F \& Tolbert, M A (eds), Reading from this place, 2: Social location and biblical interpretation in global perspective, 303-330. Minneapolis, MN: Fortress.

Segovia, F F 1998. Biblical criticism and postcolonial studies: Towards a postcolonial optic, in Sugirtharajah, R S (ed), The postcolonial Bible: Bible and postcolonialism, 1, 49-65. Sheffield: Sheffield Academic Press.

Segovia, F F 2000a. Decolonizing biblical studies: A view from the margins. Maryknoll, NY: Orbis.

Segovia, F F 2000b. Interpreting beyond borders: Postcolonial studies and diasporic studies in biblical criticism, in Segovia, F F (ed), Interpreting beyond borders: The Bible and postcolonialism, 3, 11-34. Sheffield: Sheffield Academic Press. 


\section{Postmoderne epistemologie en postkoloniale hermeneutiek}

Segovia, F F 2000c. Reading-across: Intercultural criticism and textual posture, in Segovia, F F (ed), Interpreting beyond borders: The Bible and postcolonialism, 3, 59-83. Sheffield: Sheffield Academic Press.

Simms, K 2003. Paul Ricoeur. London: Routledge. (Routledge Critical Thinkers.)

Spivak, G C 1985. Can the subaltern speak? Speculations on widow-sacrifice. Wedge, Winter/Spring, 120-130.

Spivak, G C 1987. In other worlds: Essays in cultural politics. New York: Methuen.

Spivak, G C 1990. The post-colonial critic: Interviews, strategies, dialogues, ed by S Harasym. London: Routledge.

Spivak, G C 1998. A critique of postcolonial reason: Toward a history of the vanishing present. Cambridge, MA: Harvard University Press.

Sugirtharajah, R S 1998a. Asian biblical hermeneutics and postcolonialism: Contesting the interpretations. Maryknoll, NY: Orbis. (The Bible and liberation series.)

Sugirtharajah, R S 1998b. Biblical studies after the Empire: From a colonial to a postcolonial mode of interpretation, in Sugirtharajah, R S (ed), The postcolonial Bible: The Bible and postcolonialism, 1, 12-22. Sheffield: Sheffield Academic Press.

Sugirtharajah, R S 1998c. A postcolonial exploration of collusion and construction in biblical interpretation, in Sugirtharajah, R S (ed), The postcolonial Bible: The Bible and postcolonialism, 1, 91-116. Sheffield: Sheffield Academic Press.

Sugirtharajah, R S. 1999a. Thinking about vernacular hermeneutics sitting in a metropolitan setting, in Sugirtharajah, R S (ed), Vernacular hermeneutics: The Bible and Postcolonialism, 2, 92-115. Sheffield: Sheffield Academic Press.

Sugirtharajah, R S 2001. The Bible in the Third World: Precolonial, colonial, and postcolonial. Cambridge: Cambridge University Press.

Talmon, S 1978. The "comparative method" in biblical interpretation: Principles and problems, in 1977 Congress Volume: Göttingen, 320-356. Leiden: Brill.

Thiselton, A C 1980. The two horizons: New Testament hermeneutics and philosophical description with special reference to Heidegger, Bultmann, Gadamer and Wittgenstein. Grand Rapids, MI: Eerdmans.

Thiselton, A C 1992. New horizons in hermeneutics: The theory and practice of transforming biblical reading. London: HarperCollins.

Strathern, P 2002. The essential Wittgenstein. London: Virgin Books. (The Virgin Philosophers Series.)

Van Aarde, A G 2001. The "cause of Jesus" (Sache Jesu) as the Canon behind the Canon. HTS 57(1\&2), 148-171.

Van Huyssteen, J W 1999. The shaping of rationality: Toward interdisciplinarity in theology and science. Grand Rapids, Ml: Eerdmans.

Young, R C 1987. Post-structuralism and the question of history, ed by D Attridge, G Bennington \& R C Young. New York: Cambridge University Press.

Young, R C 1990. White mythologies: Writing history and the West. New York: Routledge.

Young, R C 1995. Colonial desire: Hybridity in theory, culture and race. London: Routledge.

Young, R C 1996. Torn halves: Political conflict in literary and cultural theory. Manchester: Manchester University Press. 
Young, R C 2001. Postcolonialism: An historical introduction. Oxford: Blackwell.

Young, R C 2003. Postcolonialism: A very short introduction. Oxford: Oxford University Press.

West, G O 2001. A real presence, subsumed by Others: The Bible in colonial and postcolonial contexts. Semeia 88, 199-214.

Williams, R 1977. Marxism and literature. Oxford: Oxford University Press. 